\title{
Review
}

\section{Glycans as Targets for Drug Delivery in Cancer}

\author{
Francisca Diniz ${ }^{1,2,3}$, Pedro Coelho ${ }^{1,2,3} \mathbb{D}^{\mathbb{D}}$, Henrique O. Duarte ${ }^{1,2} \mathbb{D}$, Bruno Sarmento ${ }^{1,4,5}$, Celso A. Reis ${ }^{1,2,3,6, *(\mathbb{D})}$ \\ and Joana Gomes $1,2, *$ (D)
}

1 i3S-Instituto de Investigação e Inovação em Saúde, Universidade do Porto, 4200-135 Porto, Portugal; fdiniz@ipatimup.pt (F.D.); pcoelho@i3s.up.pt (P.C.); hduarte@ipatimup.pt (H.O.D.); bruno.sarmento@i3s.up.pt (B.S.)

2 IPATIMUP_Institute of Molecular Pathology and Immunology, University of Porto, 4200-135 Porto, Portugal 3 ICBAS-Instituto de Ciências Biomédicas Abel Salazar, Universidade do Porto, 4050-313 Porto, Portugal

4 INEB-Instituto Nacional de Engenharia Biomédica, Universidade do Porto, 4200-135 Porto, Portugal

5 CESPU-Instituto de Investigação e Formação Avançada em Ciências e Tecnologias da Saúde, 4585-116 Gandra, Portugal

6 Department of Pathology, Faculty of Medicine, University of Porto, 4200-319 Porto, Portugal

* Correspondence: celsor@ipatimup.pt (C.A.R.); joanag@ipatimup.pt (J.G.); Tel.: +351-220-408-800 (C.A.R. \& J.G.)

Citation: Diniz, F.; Coelho, P.; Duarte, H.O.; Sarmento, B.; Reis, C.A.;

Gomes, J. Glycans as Targets for Drug Delivery in Cancer. Cancers 2022, 14, 911. https://doi.org/10.3390/ cancers14040911

Academic Editor: George Tzanakakis

Received: 16 January 2022

Accepted: 10 February 2022

Published: 12 February 2022

Publisher's Note: MDPI stays neutral with regard to jurisdictional claims in published maps and institutional affiliations.

Copyright: (C) 2022 by the authors. Licensee MDPI, Basel, Switzerland. This article is an open access article distributed under the terms and conditions of the Creative Commons Attribution (CC BY) license (https:// creativecommons.org/licenses/by/ $4.0 /)$.
Simple Summary: Alterations in glycosylation are frequently observed in cancer cells. Different strategies have been proposed to increase drug delivery to the tumor site in order to improve the therapeutic efficacy of anti-cancer drugs and avoid collateral cytotoxicity. The exploitation of drug delivery approaches directed to cancer-associated glycans has the potential to pave the way for better and more efficient personalized treatment practices. Such strategies taking advantage of aberrant cell surface glycosylation patterns enhance the targeting efficiency and optimize the delivery of clinically used drugs to cancer cells, with major potential for the clinical applications.

\begin{abstract}
Innovative strategies have been proposed to increase drug delivery to the tumor site and avoid cytotoxicity, improving the therapeutic efficacy of well-established anti-cancer drugs. Alterations in normal glycosylation processes are frequently observed in cancer cells and the resulting cell surface aberrant glycans can be used as direct molecular targets for drug delivery. In the present review, we address the development of strategies, such as monoclonal antibodies, antibody-drug conjugates and nanoparticles that specific and selectively target cancer-associated glycans in tumor cells. The use of nanoparticles for drug delivery encompasses novel applications in cancer therapy, including vaccines encapsulated in synthetic nanoparticles and specific nanoparticles that target glycoproteins or glycan-binding proteins. Here, we highlight their potential to enhance targeting approaches and to optimize the delivery of clinically approved drugs to the tumor microenvironment, paving the way for improved personalized treatment approaches with major potential importance for the pharmaceutical and clinical sectors.
\end{abstract}

Keywords: antibodies; cancer; drug delivery; glycans; glycosylation; nanoparticles

\section{Introduction}

Cancer remains one of the deadliest diseases and a major burden worldwide. Over the last decades, early detection and effective treatment of cancer have been the main focus in the field. Indeed, major advances in the fields of molecular biology and the cellular basis of cancer development and progression have been made and contributed to a more comprehensive understanding of the disease [1].

Chemotherapy comprises powerful drugs against cancer that target key biological mechanisms leading to the killing of highly proliferative cells in body. However, the use and application of these drugs in cancer treatment have significant limitations, mostly 
related to the dose-limiting toxicity, poor specificity towards tumor cells and the frequent emergence of drug resistance [2,3].

Targeting cancer cells is crucial to improve the efficiency of specific drugs, avoiding drug-induced toxicity in non-neoplastic tissues, but also to aid in the detection of cancer cells and, consequently, improving diagnostics. For this reason, the development of novel and more efficient strategies to specifically target malignant cells remains of major interest $[4,5]$.

The current concept at the basis of precision oncology is that tumor-specific molecular abnormalities can be targeted with accurate, effective, and potentially less-toxic therapies. The first gateways for genomic accuracy in oncology were opened upon large preclinical work and primary discoveries of somatic, single-gene genomic abnormalities underlying oncogenic transformation that could be pharmacologically targeted. The resulting aberrantly expressed proteins can be selectively targeted by strategies using specific compounds and drugs. Recently, the use of aberrant glycans overexpressed by cancer cells have emerged as potential molecular candidates for the improvement of cancer targeted therapies $[6,7]$.

\section{Glycosylation in Cancer}

Glycosylation is a highly regulated enzymatic process comprising the addition of an initial monosaccharide to a non-glycosyl aglycone, usually a protein or a lipid. The initial sugar is further elongated with additional monosaccharides, which are linked covalently through glycosidic bonds, forming oligosaccharides or polysaccharides. Glycosylation occurs in the endoplasmic reticulum (ER) and Golgi apparatus, where the highly orchestrated and organized activity of both glycosyltransferases and glycosidases produces a vast repertoire of structurally complex and functionally diverse carbohydrate structure, or glycans [8] (Figure 1).

In protein glycosylation, glycans are typically attached via glycosidic linkages to the nitrogen atom on the side chain of asparagine (N-glycans) [9] or the oxygen atom on the side chain of threonine or serine (O-glycans) [10]. Other important type of glycoconjugates are glycosphingolipids (GSLs), cell-surface glycolipids formed by a hydrophobic ceramide core and a hydrophilic residue [11]. On the other hand, proteoglycans are glycoconjugates with one or more glycosaminoglycan (GAG) chains, such as chondroitin sulfate, heparan sulfate and keratan sulfate, attached to a protein backbone [12].

Glycans are produced in a non-templated way and their synthesis is controlled by substrate availability, gene transcription levels, tissue-specific expression patterns of glycosyltransferases and glycosidases, enzyme location within the compartments of the secretory pathway, chaperone activity, donor substrate availability, and modifications in the tertiary conformation of acceptor peptides [13,14].

Cell surface glycoconjugates form the glycocalyx, a dense gel-like protective barrier that shields the plasma membrane from physical stress while also shaping various aspects of cell surface dynamics. Furthermore, cell surface glycoconjugates are key regulators of various molecular and cellular processes, including intracellular trafficking, cell-cell interactions, cell-matrix adhesion, as well as molecular signaling, immune regulation, host-pathogen recognition and malignant transformation [13] (Figure 1).

In cancer, aberrant expression and mislocalization of glycosyltransferases and glycosidases, as well as imbalances affecting the availability of sugar nucleotide donors, lead to the emergence of aberrant glycosylation patterns (Figure 1). These cancer-derived glycan structures are key players in tumor biology, as they actively support to the various neoplastic characteristics of malignant cells [15]. In fact, it has been extensively demonstrated that cancer-associated glycans mediate the crosstalk between cancer cells and their surrounding microenvironment, contributing for the acquisition of cancer hallmarks, such as sustained proliferative signaling, resistance to cell death, immune system evasion, angiogenesis, invasion and metastization [13] (Figure 1). Receptor tyrosine kinases (RTKs) and their downstream signaling cascades actively drive neoplastic transformation. Moreover, sev- 
eral studies have demonstrated that the altered glycosylation of different RTKs (such as EGFR, ErbB2, Met, and RON) leads to their hyperactivation, which, in turn, promotes RTK-dependent malignant growth and phenotypically aggressive tumors [16-20].

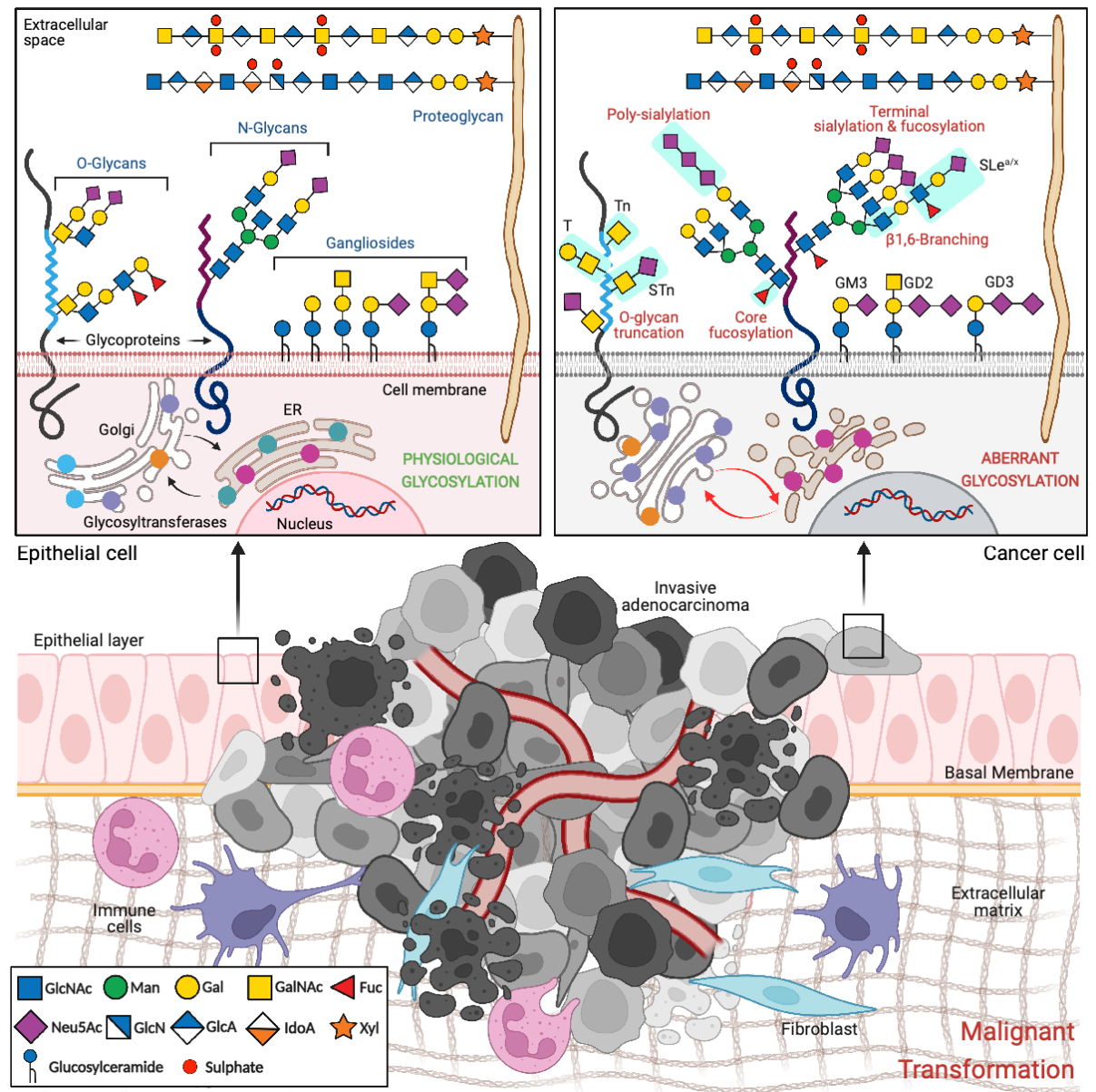

Figure 1. Glycosylation alterations during malignant transformation. Abbreviations: ERendoplasmic reticulum; Fuc —fucose; Gal—galactose; GlcN—glucosamine; GlcA—glucuronic acid; GlcNAc-N-acetylglucosamine; GalNAc-N-acetylgalactosamine; IdoA-iduronic acid; Manmannose; Neu5Ac—N-acetylneuraminic acid; STn—sialyl Tn; SLe $\mathrm{a}^{\mathrm{x}}$ — sialyl Lewis a/x; T-ThomsenFriedenreich antigen; Xyl-xylose.

\subsection{Glycans with Specific Expression in Cancer}

Aberrant glycosylation in cancer leads to the biosynthesis of tumor-associated glycans that underpin several oncogenic features leading to tumor onset and progression. Altered glycosylation encompasses the synthesis of prematurely truncated O-glycans, such as the single monosaccharide N-acetylgalactosamine (GalNAc; Tn antigen), sialyl Tn (STn) and the Thomsen-Friedenreich (T) antigen, as well as an increase in N-glycan $\beta 1,6$-branching, terminal sialylation, including the biosynthesis of polysialic acid-containing structures, and both core and antennae-linked fucosylation. These alterations support the enrichment of cell surface glycoconjugates with sialofucosylated Lewis antigens (sialyl Lewis $x\left(\operatorname{SLe}^{\mathrm{x}}\right)$ and sialyl Lewis a (SLe $\left.{ }^{\mathrm{a}}\right)$ ) [13] (Figure 1). These tumor-associated glycan structures can be present on the surface of cancer cells, but they can be also secreted or shed into the circulation and, thus, serve as potential biomarkers of disease (such as SLe ${ }^{\text {a }}$ serologically detected by CA19-9, STn detected by CA72-4, MUC16 detected by CA125 and MUC1 detected by CA15-3) [13]. Due to their unique characteristics and highly restricted expression in cancer, these tumor-associated glycans are emerging as promising targets in the context of targeted therapies. 


\subsubsection{Truncated O-Glycans}

O-glycosylation produces mature, elongated, and branched O-glycan chains, often terminally modified with sialic acids or $\mathrm{N}$-acetylneuraminic acid (Neu5Ac) through the action of sialyltransferases. A set of 20 GalNAc-transferases (encoded by GALNTs) initiates the biosynthesis of O-GalNAc glycan chains [21]. This family of enzymes transfers GalNAc to Ser/Thr residues of proteins, forming the Tn antigen (GalNAc $\alpha 1-\mathrm{O}-\mathrm{Ser} / \mathrm{Thr}$ ). Subsequently, the Tn antigen is modified by different glycosyltransferases, forming complex and mature O-glycans. Glycosyltransferase core 1 GalNAc $\beta 1,3$-galactosyltransferase 1 (C1GalT1) is responsible for adding galactose (Gal) to the Tn antigen, forming the core $1 \mathrm{O}$-glycan structure or the T antigen (Gal $\beta 1-3 \mathrm{GalNAc} \alpha 1-\mathrm{O}-\mathrm{Ser} / \mathrm{Thr})$. Core $1 \beta 3-\mathrm{Gal}-\mathrm{T}$ specific molecular chaperone (COSMC), localized in the ER, is necessary for the activation of C1GalT1 in the Golgi apparatus by preventing its misfolding, aggregation and proteasomal degradation [22]. Core 1 structures can be further modified by core $2 \beta 1,6$ $\mathrm{N}$-acetylglucosaminyltransferase (C2GnT), which adds N-acetylglucosamine (GlcNAc) to the $\mathrm{T}$ antigen, forming core $2 \mathrm{O}$-glycans. These structures can then be subsequently modified by different glycosyltransferases, including sialyl- and fucosyltransferases, forming increasingly complex structures [10].

In cancer, alterations affecting the glycosylation machinery trigger the expression of immature and truncated O-glycans, such as Tn antigen, and its sialylated form, STn (NeuAc $\alpha 2-$ 6-GalNAc $\alpha 1$-O-Ser/Thr) [13]. In non-transformed cells, early-acting enzymes responsible for core O-glycan biosynthesis, such as C1GalT1 and C2GnT, are localized in cis- and medialGolgi, and late-acting enzymes, such as sialyltransferases, are localized in the trans-Golgi. In the cancer setting, however, the overexpression of sialyltransferases leads to their aberrant distribution across all of the Golgi cisternae, where they will compete with early actingenzymes and contribute to the emergence of immature forms of O-glycan chains. One example is the overexpression of the $\alpha$-GalNAc $\alpha 2,6$-sialyltransferase I (ST6GalNAc1) that leads to the premature addition of sialic acid to form the STn antigen [23,24].

While STn expression is neglectable in normal tissues, high levels of this short O-glycan antigen have been widely reported across different epithelial-derived tumors, such as gastric, pancreatic, colorectal, and breast, and are associated with poor patient survival [25]. The mechanisms involved in STn biosynthesis include loss of C1GalT1 expression, mutations and hypermethylation of COSMC, and overexpression of ST6GalNAc1 [24,26]. STn overexpression in gastrointestinal cancer cells leads to a more aggressive phenotype, supporting the epithelial-to-mesenchymal transition (EMT) process and reducing cellcell adhesion capacity through the loss of E-cadherin expression [27-29]. Furthermore, STn-overexpressing cells are more capable of degrading and invading the surrounding extracellular matrix (ECM), being associated with poor clinical outcome and chemotherapy resistance [27-30].

In cancer, several glycoproteins are overexpressed and aberrantly glycosylated, carrying tumor-associated glycans underpinning tumor growth and metastization [15]. CD44, a transmembrane receptor for hyaluronic acid (HA) and other ECM molecules, is a wellknown glycoprotein, often overexpressed in several cancers and reported as a major carrier of truncated O-glycans in gastric cancer cells. The presence of these truncated O-glycans impact CD44 binding to HA, while also promoting hyperactivation of RON receptor [31]. Another prominent glycoprotein in the context of cancer is MUC1, a highly glycosylated transmembrane mucin, that has also been reported to be a carrier of STn in multiple cancer types, and whose overexpression has been linked to tumor growth and metastization [32].

\subsubsection{Sialylated Glycans}

One of the main terminal modifications of glycans is the addition of a negatively charged acid (Neu5Ac) to glycoproteins and GSLs, contributing to their biophysical and biological functions. Sialylation of glycoproteins plays key roles in the blood and lymphatic vasculature, being essential for cell-cell and glycoprotein-protein interactions [33-35]. The $\mathrm{SLe}^{\mathrm{x}}$ and SLe $\mathrm{S}^{\mathrm{a}}$ isomers mediate, under physiological conditions, the binding of circulating 
leukocytes to cell surface selectins expressed on activated endothelial cells during immune responses [36]. A frequent alteration that occurs in several cancers is the increased expression of SLe ${ }^{\mathrm{x}}$ and SLe ${ }^{\mathrm{a}}$. As such, tumor cells bind to vascular endothelial selectins, enhancing their migration and extravasation [37,38]. ST3Gal3, ST3Gal4 and ST3Gal6 are upregulated in different cancer types and drive the expression of SLe ${ }^{\mathrm{x}}$. In gastric cancer, high expression of ST3Gal4 is associated with an increased capacity of tumor cells to invade and metastasize. In addition, $\mathrm{SLe}^{\mathrm{x}}$ expression in tumor cells has been reported to promote proliferation, motility, angiogenesis, while protecting tumor cells from apoptosis [20].

The glycoprotein carcinoembryonic antigen (CEA) is an oncofetal antigen expressed in the developing fetus and in epithelial malignancies, but only in neglectable amounts in normal adult human tissues. In gastric carcinoma, CEA was described as the main carrier of $\mathrm{SLe}^{\mathrm{x}}$, and this glycoform was associated with a more aggressive phenotype [39].

Apart from Neu5Ac, others non-human members of sialic acid family, named Nglycolylneuraminic acid (Neu5Gc) and 2-keto-3-deoxy-D-glycero-D-galacto-nononic acid (KDN), although deficient or less abundant than Neu5Ac in humans, have also been detected with elevated levels in human cancers [40-42].

\subsection{Glycan-Binding Proteins}

Immune cells express glycan-binding protein (GBP) receptors, such as galectins, C-type lectin receptors (e.g., selectins) and sialic acid-binding immunoglobulin-like lectins (Siglecs) that, upon the recognition of specific glycan ligands, activate tolerogenic or immunogenic signaling pathways $[43,44]$. The Siglec family consists of 15 transmembrane proteins expressed by most immune cells, and can be classified into two groups: the CD33-related Siglecs with high sequence identity (Siglec-3, -5, -6, -7, -8, -9, -10, -11) and the structurally conserved Siglecs (Siglec-1, $-2,-4$ and -15) [45]. Recognition of tumor-associated glycans by GBPs expressed on immune cells leads to production of anti-inflammatory cytokines, inhibits natural killer (NK) cell-mediated cytotoxicity, and activates immunosuppressive regulatory T cells [45]. For example, Siglecs are differentially expressed by immune cells and are capable of recognizing sialic acid motifs in a linkage-specific pattern $(\alpha 2,3$, $\alpha 2,6$ or $\alpha 2,8)[43,46]$. Upon binding to sialic acids, Siglecs' intracellular immunoreceptor tyrosine-based inhibition motifs induce strong inhibitory signals that suppress the immune response [46,47].

\section{Specific Targeting of Cancer Cells}

The timely and accurate diagnosis and treatment of cancer requires the unequivocal in vivo detection and targeting of neoplastic cells. Indeed, the process of malignant transformation of healthy cells is underpinned by a plethora of molecular aberrations occurring at the genomic, epigenomic and post-translational levels. Such oncogenic events, many of which are therapeutically actionable, trigger the emergence of an array of both cell surface and intracellular tumor-specific neoantigens, whose expression is undetectable or neglectable in non-transformed cells. The highly restricted expression of such neoantigens within the cancer cell population makes them suitable molecular targets for antibody-based recognition, as well as appealing candidates for the development of both targeted therapeutic strategies and imaging systems for disease diagnosis. Since most therapeutic strategies for targeted drug delivery rely on the recognition of cell surface-residing molecules, the ideal target antigen should be broadly expressed at the membrane of tumor cells, while absent from the cell surface of healthy cells. Thus, the expression of aberrantly glycosylated forms of cell surface glycoconjugates in cancer cells makes these molecular entities appealing targets for highly selective and specific drug delivery systems (reviewed in $[6,13]$ ) (Figure 2). 


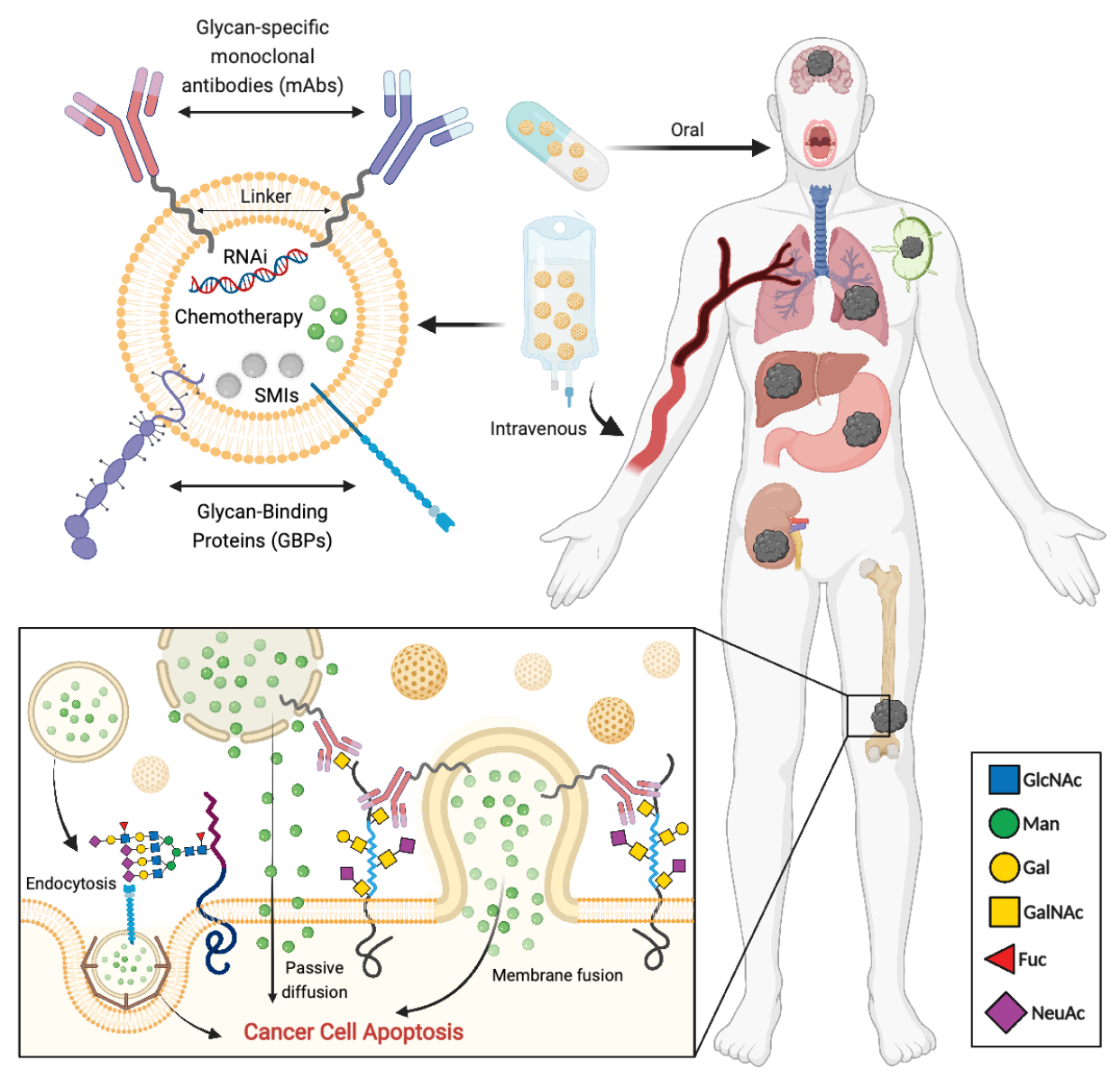

Figure 2. Strategies based on targeting cancer-associated glycans for selective and specific drug delivery systems.

\subsection{Monoclonal Antibodies}

Monoclonal antibodies (mAbs) targeting antigens that are either unique to (neoantigens) or overexpressed by malignant tissues trigger cancer cell death through a variety of effector mechanisms [48]. These include the blocking of receptor-induced proliferative signaling, the activation of anti-tumor immune responses, including antibody-dependent cellular cytotoxicity (ADCC), complement-dependent cytotoxicity (CDC) and antibodydependent cellular phagocytosis (ADCP). Antibody-triggered immune-mediated responses require the engagement of the fragment crystallizable $(\mathrm{Fc})$ region of the therapeutic $\mathrm{mAb}$ with multiple Fc receptors ( $\mathrm{FCRs}$ ) expressed at the surface of distinct immune cell populations, including NK cells, neutrophils, monocytes, dendritic cells and eosinophils [49]. Such interaction triggers the activation of a repertoire of specialized functions aiming at eliminating the cell to which the mAb is bound. Importantly, the immunoglobulin subclass further determines the capacity of a given therapeutic $\mathrm{mAb}$ to elicit immune-mediated effector responses. For instance, mAbs belonging to the IgG1 and IgG3 subclasses are able to induce the activation of ADCC and CDC, while IgG2 and IgG4 are not [50]. Several clinically approved $\mathrm{mAbs}$ target key immune checkpoints, such as the ones mediated by CTLA-4 and PD-1/PD-L1, and aim at blocking inhibitory self-tolerance signals. Such immunotherapies counteract the establishment of an immunosuppressive microenvironment and, thus, the escape of tumor cells to immune surveillance [51].

The advent of the hybridoma technology nearly 50 years ago allowed the generation of a virtually unlimited catalog of highly specific mAbs for the reliable detection of protein-, lipid- and glycan-based tumor-specific antigens. In the hybridoma system, during the immunization of a host organism, naive antibody-secreting B-cells are challenged with the purified target antigen $[52,53]$. Subsequently, activated cell clones are fused with 
myeloma cells for immortalization, generating a hybrid, clonal and antibody-producing cell line, or hybridoma. Additional phage display technology has also been applied for the production of antibodies $[54,55]$. The resulting mAbs can then undergo chimerization or, more recently, full humanization to reduce their immunogenicity, and are subsequently used as targeted therapeutic agents [56]. In the context of biomarker-guided precision oncology, the detection of the target antigen in individual tumor specimens is warranted to determine patient eligibility for $\mathrm{mAb}$-based therapeutic regimens. Such is the case of clinically approved therapeutic mAbs trastuzumab and pembrolizumab/nivolumab, used in the treatment of multiple ErbB2- and PD-L1-expressing solid tumors, respectively [57].

Over the past three decades, more than 20 therapeutic mAbs have been granted Food and Drug Administration (FDA) approval for the treatment of both solid and circulating tumors, most of which belong to the IgG1 subclass [49]. Most mAbs approved in the clinical setting target oncogenic RTKs and their cognate ligands, whose overexpression actively upregulates transcriptomic networks sustaining cancer cell proliferative signaling and angiogenic growth. Amongst the most prominent molecular targets are: two members of the epidermal growth factor receptor family (EGFR and ErbB2); the vascular endothelial growth factor receptors and ligands (VEGFR2 and VEGF); platelet-derived growth factor receptors (PDGFR $\alpha$ ); and key immune checkpoint regulators (PD-1/PD-L1, CTLA-4). Some $\mathrm{mAbs}$ directed at cancer-derived glycopeptides and other glycan-based antigens have shown promising selectivity towards cancer cells and potent cytotoxicity. These include mAbs generated against Tn/STn-modified MUC1 and MUC16 glycopeptides, and the clinically approved dinutuximab targeting the GD2 GSL, approved in the clinical setting as a second-line therapeutic agent for the treatment of high-risk neuroblastoma [58-61].

Although the clinical implementation of such compounds has proven successful in the treatment of cancer, both innate and acquired molecular resistance continue to pose a significant challenge to the efficacy of therapeutic mAbs. These include the downregulation of the cell surface molecule targeted by the mAb [62], the activation of bypass signaling circuits that circumvent mAb-mediated receptor blockade [63], and the acquisition of mutations in the target molecule that either prevent $\mathrm{mAb}$ binding or significantly reduce target affinity $[64,65]$. Furthermore, due to the poor vascular irrigation and impaired lymphatic drainage of most solid tumors, efficient extravasation, tissue penetration and homogeneous distribution of systemically administered mAbs at the target tumor site have proven challenging to achieve [66]. Furthermore, glycans have a major impact on target epitope recognition for cancer diagnosis and therapeutic stratification $[6,67,68]$. Indeed, glycan-mediated epitope masking hampers the in situ detection of therapeutic targets such as the PD-L1 immune checkpoint [68]. Enzymatic glycan removal improves PD-L1 detection in cancer patient tissues and predicts the clinical benefit from immunotherapeutic regimens [69].

The stability, immunogenicity and biological activity of therapeutic mAbs can be further optimized through glycoengineering, i.e., by rigorously controlling the glycosylation status of conserved sites at the Fc region [70]. Indeed, subtle changes in the cell culture and downstream processing procedures significantly influence the glycosylation pattern of produced mAbs, which, in turn, crucially impacts their structural and functional properties. MAbs of the IgG class harbor a conserved site for N-linked glycosylation at the Asn297. For instance, the removal of core fucose from this glycosylation site, or fucosylation, has been shown to increase the binding affinity of IgG1 mAbs to their cognate Fc $\gamma$ RIIIa receptor through reduction of steric hindrance [71,72]. The decoration of complex N-glycan structures with terminal Neu5Ac motifs, on the other hand, inhibits the binding affinity of mAbs to the Fc $\gamma$ RIIIa receptor and, consequently, dampens the activation of ADCC responses [73]. Terminal galactosylation of glycan chains decorating Asn297 has been reported to induce CDC-based immune responses [74]. Additionally, specific glycosylation profiles of therapeutic mAbs crucially govern their pharmacokinetic properties. For instance, the modification of Asn297 with oligomannosidic, or high-mannose, N-glycan species confers therapeutic mAbs faster clearance rates [75]. 
With the exceptions of mAbs targeting CD20, ErbB2 and EGFR, most therapeutic mAbs approved in the clinical setting bear modest cytotoxic activity on their own. Regardless, given their high specificity to tumor-derived antigens, mAbs represent extremely versatile platforms for the targeted delivery of cytotoxic drugs to the tumor site, such as conventional chemotherapeutic agents (antibody-drug conjugates (ADCs)), while reducing the occurrence of off-target toxicity. More recently, therapeutic antibodies have been engineered to bind to more than just two structurally identical epitopes (multi-valency), as well as to structurally distinct epitopes (multi-specificity) [76]. Such is the example of bi-specific T cell Engagers (BiTEs), which aim at stimulating anti-tumor immune-mediated synapses by simultaneously targeting a tumor antigen and the activating T cell receptor CD3 [77]. Other bi-specific mAb formulations aim at effectively neutralizing RTK-induced oncogenic signaling, by blocking cell surface activation of multiple target receptors [78].

\subsection{Antibody-Drug Conjugates}

The specificity of mAbs towards their cognate antigen can be advantageous in the targeted delivery of non-specific cytotoxic agents to cancer cells, whilst avoiding healthy tissues. Such ADC formulations currently represent the fastest growing drug class in oncology. These therapeutic formulations are composed of three main elements: a cytotoxic drug (also known as cytotoxic payload), a mAb and a flexible linker [79]. The mechanistic principle underlying this strategy is based on the highly specific recognition of a cellular surface antigen, whose expression is highly restricted to the cancer cell population, by the $\mathrm{mAb}$ moiety, and the subsequent delivery of the cytotoxic payload to the tumor tissues. Such systems can, therefore, improve the efficacy of chemotherapy and reduce systemic exposure to the drug's toxicity and side effects [80]. ADCs exert cytotoxicity through two distinct mechanisms. The primary mechanism consists in the cellular internalization of the ADC, followed by the intracellular release of the payload after linker cleavage. The secondary mechanism takes place when the payload or payload-linker permeates adjacent cells, including those with absent expression of the target antigen [79,81].

Until now, nine ADCs have been approved by FDA (Table 1). However, only five have so far received regulatory approval by both the FDA and the European Medicines Agency (EMA) for the treatment of cancer: brentuximab-vedotin, trastuzumab-emtansine (TDM-1), inotuzumab-ozogamicin, gemtuzumab-ozogamicin, and polatuzumab-vedotin. Moreover, dozens of other ADCs are currently under preclinical and clinical stages of development $[79,80]$. ADCs are thus becoming an important and viable strategy for targeting cancer cells and deliver highly cytotoxic drugs in a highly targeted manner, while protecting the integrity of non-malignant tissues.

The flexible linker of ADCs plays two important roles: ensuring that the cytotoxic payload is firmly connected to the antibody, and allowing its efficient release at the target tumor site $[79,80]$. It is essential that linkers sustain the stability of the ADC during blood circulation to guarantee its integrity until the target tumor site is reached. Linkers can be classified into two groups: cleavable and non-cleavable linkers. The cleavage of some linkers is dependent on physiological conditions, such as $\mathrm{pH}$ of the recipient cell. On the other hand, non-cleavable linkers confer the ADC improved stability while in circulation, increasing the ADC systemic half-life and decreasing off-target toxicity [80]. Of the nine currently FDA-approved ADCs (Table 1), two contain non-cleavable linkers: TDM-1 [82] (indicated for ErbB2-positive metastatic breast cancer) and belantamab-mafodotin [83] (approved for relapsed or refractory multiple myeloma).

Early developed ADCs were design to carry traditional chemotherapeutic drugs (methotrexate, doxorubicin and vinca alkaloids). However, most of these formulations had compromised efficiency which required extremely high dosing [79,80]. Currently, the most widely used payloads, such as auristatins, calicheamicins, maytansinoids and camptothecin analogues, depict higher potency at sub-nanomolar concentrations. The most commonly used payloads target either DNA replication or tubulins. Considering the nine FDA-approved ADCs, only two of them do not target DNA or tubulins: trastuzumab- 
deruxtecan [84] (approved for metastatic ErbB2-positive breast cancer) and sacituzumab govitecan [85] (indicated for triple-negative breast cancer). The payload target of these two ADCs is topoisomerase I (TOPO1). The strategy of TOPO1 inhibitors, in patients with breast cancer, is being used in advanced stages, contrarily to microtubule-targeting agents which are more broadly used in early lines of treatment. This approach makes the treated tumor more susceptible to the cytotoxicity induced by TOPO1 inhibitors and avoids the emergence of therapeutic resistance [79].

Table 1. Panel of antibody-drug conjugates (ADCs) approved by the Food and Drug Administration (FDA) and the European Medicines Agency (EMA).

\begin{tabular}{|c|c|c|c|c|c|}
\hline ADC Formulation & $\begin{array}{c}\text { Target } \\
\text { Antigen }\end{array}$ & Antibody & $\begin{array}{l}\text { Approved Clinical } \\
\text { Application }{ }^{1}\end{array}$ & $\begin{array}{c}\text { Year of } \\
\text { Approval }\end{array}$ & $\begin{array}{c}\text { Approving } \\
\text { Regulatory Entity }\end{array}$ \\
\hline $\begin{array}{l}\text { Brentuximab-vedotin } \\
\text { (SGN-35, Adcetris) }\end{array}$ & CD30 & Chimeric IgG1 & $\begin{array}{l}\text { Hodgkin's lymphoma, } \\
\text { ALCL, PTCL, MF }\end{array}$ & $2011 / 2012$ & FDA and EMA \\
\hline $\begin{array}{l}\text { Trastuzumab-emtansine } \\
\text { (T-DM1, Kadcyla) }\end{array}$ & ErbB2 & Humanized IgG1 & $\begin{array}{l}\text { ErbB2-positive } \\
\text { metastatic } \\
\text { breast cancer }\end{array}$ & 2013 & FDA and EMA \\
\hline $\begin{array}{l}\text { Inotuzumab- } \\
\text { ozogamicin } \\
\text { (Besponsa) }\end{array}$ & CD22 & $\begin{array}{c}\text { Recombinant } \\
\text { humanized IgG4 }\end{array}$ & B cell precursor ALL & 2017 & FDA and EMA \\
\hline $\begin{array}{l}\text { Gemtuzumab- } \\
\text { ozogamicin } \\
\text { (Mylotarg) }^{2}\end{array}$ & CD33 & Humanized IgG4 & CD33-positive AML & $2017 / 2018$ & FDA and EMA \\
\hline $\begin{array}{l}\text { Polatuzumab-vedotin } \\
\text { (Polivy) }\end{array}$ & CD79 & Humanized IgG1 & DLBCL & $2019 / 2020$ & FDA and EMA \\
\hline $\begin{array}{l}\text { Enfortumab-vedotin } \\
\text { (ASG-22ME, Padcev) }\end{array}$ & Nectin-4 & Human IgG1 & $\begin{array}{l}\text { Advanced } \\
\text { urothelial cancer }\end{array}$ & 2019 & FDA \\
\hline $\begin{array}{c}\text { Trastuzumab- } \\
\text { deruxtecan } \\
\text { (DS-8201a, Enhertu) }\end{array}$ & ErbB2 & Humanized IgG1 & $\begin{array}{l}\text { Metastatic } \\
\text { ErbB2-positive } \\
\text { breast cancer }\end{array}$ & 2019 & FDA \\
\hline $\begin{array}{l}\text { Sacituzumab-govitecan } \\
\text { (IMMU-132, Trodelvy) }\end{array}$ & TROP2 & Humanized IgG1 & $\begin{array}{l}\text { Triple-negative } \\
\text { breast cancer }\end{array}$ & 2020 & FDA \\
\hline $\begin{array}{l}\text { Belantamab mafodotin } \\
\text { (GSK2857916, Blenrep) }\end{array}$ & BCMA & Humanized IgG1 & $\begin{array}{l}\text { Relapsed or refractory } \\
\text { multiple myeloma }\end{array}$ & $\begin{array}{c}2020 \text { (orphan } \\
\text { drug since } 2017 \\
\text { by the EMA) }\end{array}$ & FDA \\
\hline
\end{tabular}

${ }^{1}$ ALCL, anaplastic large cell lymphoma; PTCL, peripheral T cell lymphoma; MF, mycosis fungoides; ALL, acute lymphoblastic leukaemia; AML, acute myeloid leukaemia; DLBCL, diffuse large B cell lymphoma. ${ }^{2}$ Gemtuzumabozogamicin was approved in 2000 and withdrawn from the market in 2010, then was re-approved in 2017 by the FDA.

The efficient and successful delivery of ADCs to cancer cells relies on the molecular target. Ideally, the selected target antigen should be widely expressed on the cancer cell surface to enable binding of the circulating ADC and absent or poorly expressed in healthy tissues to minimize off-target toxicity. Nevertheless, the efficacy of ADCs is also dependent of their specific binding affinity or internalization rate $[79,80]$. The molecular targets of four out of nine approved ADCs are homogenously expressed within the target cancer tissues: inotuzumab ozogamicin (indicated as B cell precursor in ALL and targeting CD22) [86], gemtuzumab ozogamicin (approved for CD33-positive AML and targeting CD33) [87], brentuximab vedotin (indicated in Hodgkin's lymphoma, ALCL, PTCL and MF and targeting CD30) [88], and polatuzumab vedotin (indicated in DLBCL and targeting CD79) [89]. ErbB2 constitutes a cell surface RTK widely expressed in epithelial-derived tumors. Thus, the use of FDA-approved ADCs for the treatment of ErbB2-addicted solid tumors, which include TDM-1 [82] and trastuzumab-deruxtecan [84], is solely indicated in tumors with confirmed ErbB2 expression. 
Most malignant tumors are able to escape immune surveillance and immune-mediated destruction. The cell surface presentation of Neu5Ac by tumor cells constitutes one of the main mechanisms underlying the capacity of tumor cells to evade immune-mediated responses. Thus, strategies targeting tumor-associated sialosides to potentiate anti-cancer immune response constitute promising therapeutic avenues. In line with this, Xiao et al. developed a trastuzumab-sialidase conjugate that selectively removes Neu5Ac moieties from ErbB2-expressing tumor cells, as well as ErbB2-negative neighboring cells, immunoediting their glycocalyx and increasing tumor cell vulnerability to ADCC [90].

\subsection{Nanoparticles: Application of Nanotherapeutics in Cancer Therapy}

In recent years, nanoparticles (NPs) have been extensively explored in biomedical research. Nanomedicines have several advantages over conventional cancer therapies. Firstly, they offer greater efficiency in early detection, diagnosis, imaging, and treatment of cancers [91]. Secondly, nanoscale engineering allows the production of multifunctional and "smart" NPs with extraordinary capacities, such as the ability to cross biological barriers, to target specific cells, and to control the drug release [5]. NPs have been widely used in the cancer field due to their high sensitivity for diagnostic-based imaging but also due to their use as alternative tools for targeted drug delivery with reduced systemic toxicity. The progress and improvements of nanosystems make them promising tools in clinical oncology [92].

The most prominent feature of therapeutic NPs is their capacity to efficiently encapsulate drugs with poor solubility, which they then efficiently deliver to the target tissue, while minimizing off-target toxicity [92] (Figure 2). Indeed, specific characteristics of NPs determine nanocarrier drug delivery efficiency and biodistribution in the body [5]. The most efficient way for a NP to systematically deliver a drug to the target tumor site is by remaining in circulation for a prolonged period. To do so, the nanodrug delivery efficiency can be controlled by modulating NP size and surface physicochemical characteristics [5].

Despite its known toxicity to non-cancer tissues, chemotherapy remains the most widely used therapeutic strategy in the cancer clinical setting. Doxorubicin, 5-fluoroucill and paclitaxel are known as potent anti-cancer drugs for the treatment of multiple cancers. Although these drugs efficiently impair cancer cell proliferation and growth, their systemic side effects and toxicity are also observed in healthy tissues, especially those characterized by significant cellular proliferation and turnover. For these reasons, several potent anti-tumor agents have not progressed into further clinical development [92]. In this context, NPs may represent a valuable alternative to reduce a drug's off-target adverse effects, by restricting the release of the chemotherapeutic agents to the target tumor site. Nevertheless, there are several challenges related to the use of nanotherapeutic products, such as unintended NP accumulation, as well as pharmacokinetic, physicochemical and safety profiles [93-95].

Decorating Nanoparticles with Monoclonal Antibodies for Selective and Efficient Cancer Cell Targeting

The type of target tissue is determinant when designing nanodrugs. Nanocarriers can deliver drugs to tumors by two different mechanisms: passive and active targeting.

Passive targeting is accomplished by delivering NPs to defined organs via two different mechanisms, such as the reticuloendothelial system, or the enhanced permeability and retention (EPR) system $[93,96]$. However, these strategies have some limitations inherent to NP physicochemical properties and the pathophysiological features of cancer tissues. Firstly, the size and surface properties of NPs need to be highly controlled to avoid both renal clearance and uptake by the mononuclear phagocyte system, both of which reduce their circulation half-life. Besides, strict control over the NP size is also important to avoid NP accumulation by the EPR effect at the tumor site, through both convection and diffusion processes. This is expected to affect NPs in the 100-400 nm diameter range $[93,95,96]$. Furthermore, several chemotherapeutic drugs may induce multiple-drug resistance, which 
makes anti-cancer therapy become inefficient due to the resistance of cancer cells. This is a consequence of the ineffective drug delivery mechanism that lacks controlled diffusion into the tumor, accumulating NPs improperly in tissues and preventing their prolonged circulation in the bloodstream $[5,93]$. The passive strategy is further limited in certain hypovascular tumors, which do not exhibit the retention effect and are supplied by vessels depicting heterogeneous permeability and distribution. Besides, the drug delivery process by passive targeting lacks control concerning the random nature of targeting and the inefficient drug diffusion into a tumor. Thus, NPs based on active targeting can help overcome these limitations [93].

Active targeting is based on the conjugation of NPs with molecules that specifically bind to a receptor whose expression is restricted to the target cell population, while depicting neglectable expression in normal cells [5]. The interaction between a ligand/mAb and its cognate receptor may induce NP internalization via receptor-mediated endocytosis and consequent intracellular drug release. Hence, non-specific interactions among NPs and normal cells will be minimized, resulting in decreased systemic side effects and increased cytotoxicity to tumor cells when applied to anti-cancer drug delivery $[5,95,96]$. Obviously, the success of ligand-receptor interaction depends on the amount of ligand/mAb at the NP surface, ligand orientation, and target receptor expression in the target cells. In this context, increasing the number of binding sites or generating novel binding sites are considered promising strategies to overcome the current limitations of active targeting $[5,95,96]$. Multiple ligands have been applied to functionalize NPs in the active targeting setting. Still, mAbs, mainly from IgG subtypes, remain the most widely used molecules to achieve active tumor targeting $[93,97]$.

In the early stages of development, full antibodies were used as targeting ligands. Nevertheless, multiple challenges, including immunogenicity, poor stability, fast degradation and lower efficacy further encouraged the use of antibody fragments, which allow for higher loading capacities due to reduction in crowding, superior orientation of targeting ligands and reduced variability in NP diameter constant [93,97]. A NP functionalized with an engineered human Fab targeting the alternatively-spliced CD44v6 was developed, owing to its frequent overexpression in cancer tissues. Their nanodelivery system is characterized by specificity, optimal ligand orientation and low toxicity. Finally, they produced a NP capable of strongly binding to a CD44v6-derived peptide and, more crucially, to cells with endogenous CD44v6 expression, as opposed to CD44v6-negative cells [98,99].

\section{Sweetening Precision Oncology with Glycan-Directed Nanoparticles}

As previously mentioned, aberrant protein glycosylation constitutes an incontrovertible hallmark of the malignant transformation of human cells and tissues [6,13]. Moreover, the restricted expression of glycan-based cell surface neoantigens to cancer cells makes these molecular entities promising targets for selective anti-cancer drug delivery. Over the last decade, several efforts have been made to integrate nanotechnology and carbohydrate field for the targeted and controlled delivery of cancer therapeutic agents. Several studies have demonstrated the importance of using glycosylated NPs for therapeutic purposes (reviewed in $[95,100]$ ).

\subsection{Vaccines Encapsulated in Synthetic Glycan-Targeting Nanoparticles with Glycan Targeting}

Over the last decades, the development of vaccines has led to a significant expansion of the human life expectancy, with a positive impact on long-term protective immunity of the population [101]. The mechanism underlying therapeutic cancer vaccines relies on the modulation of the host's immune response against malignancies. Cancer cells are known to express a series of tumor-associated antigens that suppress the cytotoxic activity of $\mathrm{T}$ cell responses. Such is the case of STn- and Tn-decorated MUC1, which is overexpressed in several malignant tumors [95].

NPs can exert optimal actions both as delivery systems and as adjuvants, with the ability to extensively enhance immune responses while ensuring minimal toxicity [102]. A 
study conducted by Liu et al. [103] produced an anti-tumor vaccine in which a MUC1 glycopeptide was used as the target tumor-associated immunogen, the $\alpha$-galactosylceramide ( $\alpha$-GalCer) acted as an immune adjuvant, and gold-based NPs (AuNPs) as the multivalent carriers. The developed vaccine triggered a significant and durable antibody response, through specific binding of immunized serum to MUC1-expressing breast cancer cells. In another study, Cai et al. [104] developed a vaccine in which MUC1 glycopeptides were covalently linked to CD4 T-cell peptide epitopes and polyethylene glycol (PEG) combined with AuNPs. This formulation was able to promote antigen presentation by antigen presenting cells, modulating T-cell activation and MHC II-restricted T- and B-cell cooperation. Finally, Mocan et al. [105] demonstrated that AuNPs functionalized with a MUC1 protein fragment generated efficient anti-cancer responses via macrophage activation and polarization towards an inflammatory phenotype (M1). A polymerizable version of the Tn antigen was conjugated to AuNPs and was able to induce the strong and durable production of anti-Tn antibodies, demonstrating that the efficiency of glycan-directed vaccines is comparable to that of formulations targeting entirely peptidic antigens [106].

More recently, a novel antigen delivery system using MUC4, a glycoprotein highly overexpressed in pancreatic tumors, was decorated with the $\mathrm{T}$ antigen at different sites. Their synthetic vaccine targets antigen-presenting cells (APC) expressing dectin-1, a C-type lectin known to bind $\beta 1,3$-glucans. The obtained results showed that these particles induce strong in vivo immune responses, such as production of antibodies and the activation and proliferation of antigen-recognizing T-cells [107].

Some studies also focus on the new strategy based on the selective targets of the mannose receptor expressed in APC, such as dendritic cells and macrophages. It demonstrated a simultaneous enhancement of antigen-specific CD4+ and CD8+ T-cell responses by mannan-decorated poly(lactic-co-glycolic-acid) (PLGA) NPs with ovalbumin encapsulated, in comparison with non-decorated NPs [108]. In addition, drug-free mannosylated liposome NPs were also used to inhibit tumor growth by promoting the polarization of tumor-associated macrophages. It was shown that the induction of the M1 phenotype is associated to the increase of antitumor immune efficacy of immunomodulators [109].

\subsection{Nanoparticle Strategies Using Glycoproteins}

Several reports demonstrated the use of aptamers to target carbohydrate moieties, such as Neu5Ac, instead of mAbs [91,110-113]. Aptamers are synthetic oligonucleotides or peptide molecules with a small size, lower production cost, high specificity, and reduced immunogenicity [114]. A recent study [115] has developed an anti-MUC1 aptamer conjugated to a chitosan-based NP to co-deliver insulin-like growth factor receptor 1 (IGF-1R) siRNA and the docetaxel chemotherapeutic. This nanoformulation was conjugated with an anti-MUC1 aptamer and was shown to efficiently bind to MUC1-overexpressing metastatic breast cancer cells. Moreover, the developed NP was shown to be efficiently internalized by malignant cells and produce the desired downregulation of IGF-1R expression. Sayari et al. [111] have developed a similar nanocarrier system for the delivery of SN38, the active metabolite of irinotecan, to colon cancer cells. The poor solubility and high toxicity of SN38 have so far precluded its clinical use. However, the encapsulation and specific delivery of this compound to cancer cells may help overcome both these limitations. A MUC1-directed aptamer has been further conjugated with a mesoporous silica NP. The NP was loaded with epirubicin, a cytotoxic drug commonly used to treat breast cancer in the adjuvant setting, and depicted increased uptake and cytotoxicity in breast cancer cells [112]. Perepelyuk et al. evaluated the therapeutic efficacy of MUC1-aptamer functionalized hybrid NPs in lung tumor-bearing mice. This hybrid nanosystem was loaded miRNA-29b, a microRNA targeting DNA methyltransferases, and was shown to increase its specific delivery to the target cells and tissues [113]. Lastly, Yu et al. [110] also reported the potential of a MUC1 protein aptamer when as a targeting agent. Paclitaxel was loaded in aptamer-conjugated NPs of PLGA and validated in a MUC1-overexpressing breast cancer cells. 
CD44 constitutes an additional appealing molecular candidate for anti-cancer targeted drug delivery [116]. One study has developed NPs coated with HA-appended PEGPLGA polymers for the specific targeting of CD44-expressing triple-negative breast cancer cells. Such formulation, loaded with antisense miR-34a, depicted enhanced stability and potent in vivo toxicity [117]. A similar approach has been developed in the bladder cancer context, using CD44-targeting NPs loaded with anti-Bcl2 siRNAs [118]. Furthermore, PLGA-based NPs decorated with a Fab recognizing the CD44v6 variant highly expressed by gastrointestinal cancer cells have been developed [119].

Some other studies have employed methods to evaluate CEA, a cell surface glycoprotein overexpressed in several tumors, as a therapeutic target. A strategy was created for the targeting of triple-negative breast cancer using CEA-directed iron NPs, which depicted an enhanced tumor targeting capacity [120]. Additionally, CEA-targeting PLGA-PEG NPs loaded with paclitaxel have been demonstrated to selectively bind and trigger the death of CEA-expressing colorectal cancer cells [121].

\subsection{Glycan-Targeting Nanoparticles}

Targeting cancer-associated glycan epitopes is another promising strategy to achieve targeted drug delivery in cancer tissues. A commonly targeted glycan is SLe ${ }^{a}$, due to its high expression during malignant transformation. In this context, functionalized PLGA NPs with a mAb targeting SLe ${ }^{\mathrm{a}}$ and loaded with paclitaxel and 5-FU have been developed [122]. More recently, Palma-Chavez et al. developed and characterized a PLGA-based multistage delivery system for improved drug delivery to SLe ${ }^{\mathrm{a}}$-expressing inflamed vascular endothelium [123].

\subsection{Nanoparticles Strategies Using Glycan-Binding Proteins}

GBPs regulate the crosstalk between distinct sets of immune cell populations and tumor cells. By actively supporting the establishment of an immunosuppressive microenvironment, GBPs have emerged as promising targets of more efficient immunotherapies. Several studies have developed NPs functionalized with a mAb targeting Siglec-3 (CD33), which is abundantly expressed on the surface of acute myeloid leukaemia cells [124-127]. Furthermore, novel bi-specific liposomal-based NP T cell engagers (nanoTCEs) are conjugated with two mAbs targeting two distinct epitopes, one being a cancer antigen, and the other the Siglec-3 [124]. This formulation has shown to be efficient in the targeting and killing of AML cells, both in vitro and in vivo.

Another attractive target is Siglec-1 (CD169/sialoadhesin), due to is ubiquitous expression on macrophages. Chen et al. described a strategy using liposomal NPs with high binding affinity towards glycan-based ligands of Siglec-1 [128].

Several studies have been conducted using NPs functionalized with carbohydraterecognizing lectins [129-133]. For instance, the mannose-binding concanavalin A was used to functionalize NPs and target sialic acids $[129,133]$. In addition, the conjugation of the wheat germ agglutinin to NPs loaded with anti-tumor chemotherapeutics has been shown to significantly enhance cancer cell-specific uptake, while minimizing off-target cytotoxicity [130]. Similar strategies have been employed for the targeting of cancer cells enriched in fucosylated antigens, such as Lewis $x\left(\mathrm{Le}^{\mathrm{x}}\right)$, using the fucose-recognizing lectins aleuria aurantia lectin [131] and the lotus tetragonolobus lectin [132].

\section{Future Perspectives}

Development of therapeutic strategies using NPs directed at glycans constitutes an emerging and promising field. Recent studies demonstrate that NPs, with their unique properties, represent excellent platforms to be developed and applied in the new era of personalized target therapy. They not only improve the release and therapeutic efficacy of anti-cancer drugs at the target side, but also reduce cytotoxicity and a drug's off-target effects.

Several issues regarding NP formulation should be ensured in the future. The high level of consistency in the large-scale production, characterization, and reproducibility 
of the engineered NPs must be guaranteed. Besides, a better understanding of the NP interaction with the immune system and their in vivo biodistribution is crucial which, together with their evaluation in preclinical studies using suitable animal models, will set the basis for future preliminary human trials. In addition, the NPs' fate and their biodegradability must be carefully evaluated, considering nanotoxicology issues.

The aberrant glycosylation landscape of tumor cells constitutes a major opportunity for developing advanced targeted therapies. The high prevalence of such glycosylation alterations expressed within the glycocalyx of tumor cells make them appealing target candidates for the antibody-based target delivery of NPs. Additionally, glycan recognizing molecules, such as antibodies, lectins, and other GBPs, unlock several potential strategies for clinical beneficial targeted therapeutics, ultimately improving patient clinical outcome.

Finally, the presently available nanoformulations targeting glycans have the potential to undergo improvements in order to ensure that these nanosystems could be efficiently translated into clinical practice.

Author Contributions: F.D., P.C., H.O.D., B.S., C.A.R. and J.G. wrote, reviewed, and edited the manuscript. H.O.D. prepared the figures. All authors have read and agreed to the published version of the manuscript.

Funding: This work is a result of the project Norte-01-0145-FEDER-000051-“Cancer Research on Therapy Resistance: From Basic Mechanisms to Novel Targets", supported by Norte Portugal Regional Operational Programme (NORTE 2020), under the PORTUGAL 2020 Partnership Agreement, through the European Regional Development Fund (FEDER); and by National Funds through the Portuguese Foundation for Science and Technology (FCT): PTDC/MEC-ONC/0491/2021 to CR and JG, and the doctoral fellowship SFRH/BD/137896/2018 to FD.

Conflicts of Interest: The authors declare no conflict of interest.

\section{References}

1. Hanahan, D.; Weinberg, R.A. Hallmarks of cancer: The next generation. Cell 2011, 144, 646-674. [CrossRef] [PubMed]

2. Liu, Y.-P.; Zheng, C.-C.; Huang, Y.-N.; He, M.-L.; Xu, W.W.; Li, B. Molecular mechanisms of chemo- and radiotherapy resistance and the potential implications for cancer treatment. MedComm 2021, 2, 315-340. [CrossRef]

3. Eichler, H.G.; Thomson, A.; Eichler, I.; Schneeweiss, S. Assessing the relative efficacy of new drugs: An emerging opportunity. Nat. Rev. Drug Discov. 2015, 14, 443-444. [CrossRef] [PubMed]

4. Zugazagoitia, J.; Guedes, C.; Ponce, S.; Ferrer, I.; Molina-Pinelo, S.; Paz-Ares, L. Current Challenges in Cancer Treatment. Clin. Ther. 2016, 38, 1551-1566. [CrossRef] [PubMed]

5. Raj, S.; Khurana, S.; Choudhari, R.; Kesari, K.K.; Kamal, M.A.; Garg, N.; Ruokolainen, J.; Das, B.C.; Kumar, D. Specific targeting cancer cells with nanoparticles and drug delivery in cancer therapy. Semin. Cancer Biol. 2021, 69, 166-177. [CrossRef]

6. Mereiter, S.; Balmana, M.; Campos, D.; Gomes, J.; Reis, C.A. Glycosylation in the Era of Cancer-Targeted Therapy: Where Are We Heading? Cancer Cell 2019, 36, 6-16. [CrossRef]

7. Smith, B.A.H.; Bertozzi, C.R. The clinical impact of glycobiology: Targeting selectins, Siglecs and mammalian glycans. Nat. Rev. Drug Discov. 2021, 20, 217-243. [CrossRef]

8. Colley, K.J.; Varki, A.; Kinoshita, T. Cellular Organization of Glycosylation. In Essentials of Glycobiology; Varki, A., Cummings, R.D., Esko, J.D., Stanley, P., Hart, G.W., Aebi, M., Darvill, A.G., Kinoshita, T., Packer, N.H., Prestegard, J.H., et al., Eds.; Cold Spring Harbor Laboratory Press: Cold Spring Harbor, NY, USA, 2015; pp. 41-49.

9. Stanley, P.; Taniguchi, N.; Aebi, M. N-Glycans. In Essentials of Glycobiology; Varki, A., Cummings, R.D., Esko, J.D., Stanley, P., Hart, G.W., Aebi, M., Darvill, A.G., Kinoshita, T., Packer, N.H., Prestegard, J.H., et al., Eds.; Cold Spring Harbor Laboratory Press: Cold Spring Harbor, NY, USA, 2015; pp. 99-111.

10. Brockhausen, I.; Stanley, P. O-GalNAc Glycans. In Essentials of Glycobiology; Varki, A., Cummings, R.D., Esko, J.D., Stanley, P., Hart, G.W., Aebi, M., Darvill, A.G., Kinoshita, T., Packer, N.H., Prestegard, J.H., et al., Eds.; Cold Spring Harbor Laboratory Press: Cold Spring Harbor, NY, USA, 2015; pp. 113-123.

11. Schnaar, R.L.; Kinoshita, T. Glycosphingolipids. In Essentials of Glycobiology; Varki, A., Cummings, R.D., Esko, J.D., Stanley, P., Hart, G.W., Aebi, M., Darvill, A.G., Kinoshita, T., Packer, N.H., Prestegard, J.H., et al., Eds.; Cold Spring Harbor Laboratory Press: Cold Spring Harbor, NY, USA, 2015; pp. 125-135.

12. Lindahl, U.; Couchman, J.; Kimata, K.; Esko, J.D. Proteoglycans and Sulfated Glycosaminoglycans. In Essentials of Glycobiology; Varki, A., Cummings, R.D., Esko, J.D., Stanley, P., Hart, G.W., Aebi, M., Darvill, A.G., Kinoshita, T., Packer, N.H., Prestegard, J.H., et al., Eds.; Cold Spring Harbor Laboratory Press: Cold Spring Harbor, NY, USA, 2015; pp. $207-221$.

13. Pinho, S.S.; Reis, C.A. Glycosylation in cancer: Mechanisms and clinical implications. Nat. Rev. Cancer 2015, 15, 540-555. [CrossRef] 
14. Schjoldager, K.T.; Narimatsu, Y.; Joshi, H.J.; Clausen, H. Global view of human protein glycosylation pathways and functions. Nat. Rev. Mol. Cell Biol. 2020, 21, 729-749. [CrossRef]

15. Stowell, S.R.; Ju, T.; Cummings, R.D. Protein glycosylation in cancer. Annu. Rev. Pathol. 2015, 10, 473-510. [CrossRef]

16. Britain, C.M.; Holdbrooks, A.T.; Anderson, J.C.; Willey, C.D.; Bellis, S.L. Sialylation of EGFR by the ST6Gal-I sialyltransferase promotes EGFR activation and resistance to gefitinib-mediated cell death. J. Ovarian Res. 2018, 11, 12. [CrossRef] [PubMed]

17. Mereiter, S.; Magalhães, A.; Adamczyk, B.; Jin, C.; Almeida, A.; Drici, L.; Ibáñez-Vea, M.; Gomes, C.; Ferreira, J.A.; Afonso, L.P.; et al. Glycomic analysis of gastric carcinoma cells discloses glycans as modulators of RON receptor tyrosine kinase activation in cancer. Biochim. Biophys. Acta 2016, 1860, 1795-1808. [CrossRef] [PubMed]

18. Duarte, H.O.; Rodrigues, J.G.; Gomes, C.; Hensbergen, P.J.; Ederveen, A.L.H.; de Ru, A.H.; Mereiter, S.; Polonia, A.; Fernandes, E.; Ferreira, J.A.; et al. ST6Gal1 targets the ectodomain of ErbB2 in a site-specific manner and regulates gastric cancer cell sensitivity to trastuzumab. Oncogene 2021, 40, 3719-3733. [CrossRef]

19. Rodrigues, J.G.; Duarte, H.O.; Gomes, C.; Balmaña, M.; Martins Á, M.; Hensbergen, P.J.; de Ru, A.H.; Lima, J.; Albergaria, A.; van Veelen, P.A.; et al. Terminal $\alpha 2,6$-sialylation of epidermal growth factor receptor modulates antibody therapy response of colorectal cancer cells. Cell Oncol. 2021, 44, 835-850. [CrossRef]

20. Gomes, C.; Osorio, H.; Pinto, M.T.; Campos, D.; Oliveira, M.J.; Reis, C.A. Expression of ST3GAL4 leads to SLe(x) expression and induces c-Met activation and an invasive phenotype in gastric carcinoma cells. PLoS ONE 2013, 8, e66737. [CrossRef] [PubMed]

21. Bennett, E.P.; Mandel, U.; Clausen, H.; Gerken, T.A.; Fritz, T.A.; Tabak, L.A. Control of mucin-type O-glycosylation: A classification of the polypeptide GalNAc-transferase gene family. Glycobiology 2012, 22, 736-756. [CrossRef] [PubMed]

22. Ju, T.; Aryal, R.P.; Kudelka, M.R.; Wang, Y.; Cummings, R.D. The Cosmc connection to the Tn antigen in cancer. Cancer Biomark 2014, 14, 63-81. [CrossRef] [PubMed]

23. Sewell, R.; Backstrom, M.; Dalziel, M.; Gschmeissner, S.; Karlsson, H.; Noll, T.; Gatgens, J.; Clausen, H.; Hansson, G.C.; Burchell, J.; et al. The ST6GalNAc-I sialyltransferase localizes throughout the Golgi and is responsible for the synthesis of the tumor-associated sialyl-Tn O-glycan in human breast cancer. J. Biol. Chem. 2006, 281, 3586-3594. [CrossRef]

24. Marcos, N.T.; Bennett, E.P.; Gomes, J.; Magalhaes, A.; Gomes, C.; David, L.; Dar, I.; Jeanneau, C.; DeFrees, S.; Krustrup, D.; et al ST6GalNAc-I controls expression of sialyl-Tn antigen in gastrointestinal tissues. Front. Biosci. 2011, 3, 1443-1455. [CrossRef]

25. Julien, S.; Videira, P.A.; Delannoy, P. Sialyl-tn in cancer: (how) did we miss the target? Biomolecules 2012, 2, 435-466. [CrossRef]

26. Munkley, J. The Role of Sialyl-Tn in Cancer. Int. J. Mol. Sci. 2016, 17, 275. [CrossRef]

27. Radhakrishnan, P.; Dabelsteen, S.; Madsen, F.B.; Francavilla, C.; Kopp, K.L.; Steentoft, C.; Vakhrushev, S.Y.; Olsen, J.V.; Hansen, L.; Bennett, E.P.; et al. Immature truncated O-glycophenotype of cancer directly induces oncogenic features. Proc. Natl. Acad. Sci. USA 2014, 111, E4066-E4075. [CrossRef] [PubMed]

28. Thomas, D.; Sagar, S.; Caffrey, T.; Grandgenett, P.M.; Radhakrishnan, P. Truncated O-glycans promote epithelial-to-mesenchymal transition and stemness properties of pancreatic cancer cells. J. Cell Mol. Med. 2019, 23, 6885-6896. [CrossRef] [PubMed]

29. Freitas, D.; Campos, D.; Gomes, J.; Pinto, F.; Macedo, J.A.; Matos, R.; Mereiter, S.; Pinto, M.T.; Polonia, A.; Gartner, F.; et al. Oglycans truncation modulates gastric cancer cell signaling and transcription leading to a more aggressive phenotype. EBioMedicine 2019, 40, 349-362. [CrossRef]

30. Miles, D.W.; Happerfield, L.C.; Smith, P.; Gillibrand, R.; Bobrow, L.G.; Gregory, W.M.; Rubens, R.D. Expression of sialyl-Tn predicts the effect of adjuvant chemotherapy in node-positive breast cancer. Br. J. Cancer 1994, 70, 1272-1275. [CrossRef] [PubMed]

31. Mereiter, S.; Martins Á, M.; Gomes, C.; Balmaña, M.; Macedo, J.A.; Polom, K.; Roviello, F.; Magalhães, A.; Reis, C.A. O-glycan truncation enhances cancer-related functions of CD44 in gastric cancer. FEBS Lett. 2019, 593, 1675-1689. [CrossRef]

32. Pinho, S.; Marcos, N.T.; Ferreira, B.; Carvalho, A.S.; Oliveira, M.J.; Santos-Silva, F.; Harduin-Lepers, A.; Reis, C.A. Biological significance of cancer-associated sialyl-Tn antigen: Modulation of malignant phenotype in gastric carcinoma cells. Cancer Lett. 2007, 249, 157-170. [CrossRef]

33. D'Addio, M.; Frey, J.; Otto, V.I. The manifold roles of sialic acid for the biological functions of endothelial glycoproteins. Glycobiology 2020, 30, 490-499. [CrossRef]

34. McEver, R.P. Role of selectins in leukocyte adhesion to platelets and endothelium. Ann. N. Y. Acad. Sci. 1994, 714, 185-189. [CrossRef]

35. McEver, R.P. Selectins: Initiators of leucocyte adhesion and signalling at the vascular wall. Cardiovasc. Res. 2015, 107, 331-339. [CrossRef]

36. Dall'Olio, F.; Pucci, M.; Malagolini, N. The Cancer-Associated Antigens Sialyl Lewis(a/x) and Sd(a): Two Opposite Faces of Terminal Glycosylation. Cancers 2021, 13, 5273. [CrossRef]

37. Jin, F.; Wang, F. The physiological and pathological roles and applications of sialyl Lewis $\mathrm{x}$, a common carbohydrate ligand of the three selectins. Glycoconj J. 2020, 37, 277-291. [CrossRef]

38. Borsig, L. Selectins in cancer immunity. Glycobiology 2018, 28, 648-655. [CrossRef] [PubMed]

39. Gomes, C.; Almeida, A.; Barreira, A.; Calheiros, J.; Pinto, F.; Abrantes, R.; Costa, A.; Polonia, A.; Campos, D.; Osorio, H.; et al. Carcinoembryonic antigen carrying $\mathrm{SLe}(\mathrm{X})$ as a new biomarker of more aggressive gastric carcinomas. Theranostics 2019, 9, 7431-7446. [CrossRef] [PubMed]

40. Samraj, A.N.; Läubli, H.; Varki, N.; Varki, A. Involvement of a non-human sialic Acid in human cancer. Front. Oncol. 2014, 4, 33. [CrossRef] 
41. Inoue, S.; Lin, S.L.; Chang, T.; Wu, S.H.; Yao, C.W.; Chu, T.Y.; Troy, F.A., 2nd; Inoue, Y. Identification of free deaminated sialic acid (2-keto-3-deoxy-D-glycero-D-galacto-nononic acid) in human red blood cells and its elevated expression in fetal cord red blood cells and ovarian cancer cells. J. Biol. Chem. 1998, 273, 27199-27204. [CrossRef] [PubMed]

42. Wang, F.; Xie, B.; Wang, B.; Troy, F.A., II. LC-MS/MS glycomic analyses of free and conjugated forms of the sialic acids, Neu5Ac, Neu5Gc and KDN in human throat cancers. Glycobiology 2015, 25, 1362-1374. [CrossRef]

43. Macauley, M.S.; Crocker, P.R.; Paulson, J.C. Siglec-mediated regulation of immune cell function in disease. Nat. Rev. Immunol. 2014, 14, 653-666. [CrossRef] [PubMed]

44. Cummings, R.D.; McEver, R.P. C-Type Lectins. In Essentials of Glycobiology; Varki, A., Cummings, R.D., Esko, J.D., Stanley, P., Hart, G.W., Aebi, M., Darvill, A.G., Kinoshita, T., Packer, N.H., Prestegard, J.H., et al., Eds.; Cold Spring Harbor Laboratory Press: Cold Spring Harbor, NY, USA, 2015; pp. 435-452.

45. Läubli, H.; Varki, A. Sialic acid-binding immunoglobulin-like lectins (Siglecs) detect self-associated molecular patterns to regulate immune responses. Cell Mol. Life Sci. 2020, 77, 593-605. [CrossRef]

46. Lubbers, J.; Rodriguez, E.; van Kooyk, Y. Modulation of Immune Tolerance via Siglec-Sialic Acid Interactions. Front. Immunol. 2018, 9, 2807. [CrossRef]

47. RodrÍguez, E.; Schetters, S.T.T.; van Kooyk, Y. The tumour glyco-code as a novel immune checkpoint for immunotherapy. Nat. Rev. Immunol. 2018, 18, 204-211. [CrossRef]

48. Scott, A.M.; Wolchok, J.D.; Old, L.J. Antibody therapy of cancer. Nat. Rev. Cancer 2012, 12, 278-287. [CrossRef]

49. Zahavi, D.; Weiner, L. Monoclonal Antibodies in Cancer Therapy. Antibodies 2020, 9, 34. [CrossRef] [PubMed]

50. Weiner, L.M.; Surana, R.; Wang, S. Monoclonal antibodies: Versatile platforms for cancer immunotherapy. Nat. Rev. Immunol. 2010, 10, 317-327. [CrossRef] [PubMed]

51. Mayes, P.A.; Hance, K.W.; Hoos, A. The promise and challenges of immune agonist antibody development in cancer. Nat. Rev. Drug Discov. 2018, 17, 509-527. [CrossRef] [PubMed]

52. Schwaber, J.; Cohen, E.P. Human $\mathrm{x}$ mouse somatic cell hybrid clone secreting immunoglobulins of both parental types. Nature 1973, 244, 444-447. [CrossRef]

53. Köhler, G.; Milstein, C. Continuous cultures of fused cells secreting antibody of predefined specificity. Nature 1975, $256,495-497$. [CrossRef]

54. Mancini, N.; Carletti, S.; Perotti, M.; Canducci, F.; Mammarella, M.; Sampaolo, M.; Burioni, R. Phage display for the production of human monoclonal antibodies against human pathogens. New MicroBiol. 2004, 27, 315-328.

55. Thie, H.; Meyer, T.; Schirrmann, T.; Hust, M.; Dübel, S. Phage display derived therapeutic antibodies. Curr. Pharm. Biotechnol. 2008, 9, 439-446. [CrossRef]

56. Harding, F.A.; Stickler, M.M.; Razo, J.; DuBridge, R.B. The immunogenicity of humanized and fully human antibodies: Residual immunogenicity resides in the CDR regions. MAbs 2010, 2, 256-265. [CrossRef]

57. Catenacci, D.V.T.; Chung, H.C.; Shen, L.; Moehler, M.; Yoon, H.H.; Rosales, M.K.; Kang, Y.K. Safety and efficacy of HER2 blockade by trastuzumab-based chemotherapy-containing combination strategies in HER2+ gastroesophageal adenocarcinoma. ESMO Open 2021, 7, 100360. [CrossRef]

58. Klinger, M.; Farhan, H.; Just, H.; Drobny, H.; Himmler, G.; Loibner, H.; Mudde, G.C.; Freissmuth, M.; Sexl, V. Antibodies directed against Lewis-Y antigen inhibit signaling of Lewis-Y modified ErbB receptors. Cancer Res. 2004, 64, 1087-1093. [CrossRef]

59. Beatson, R.; Tajadura-Ortega, V.; Achkova, D.; Picco, G.; Tsourouktsoglou, T.D.; Klausing, S.; Hillier, M.; Maher, J.; Noll, T.; Crocker, P.R.; et al. The mucin MUC1 modulates the tumor immunological microenvironment through engagement of the lectin Siglec-9. Nat. Immunol. 2016, 17, 1273-1281. [CrossRef]

60. Thomas, D.; Sagar, S.; Liu, X.; Lee, H.R.; Grunkemeyer, J.A.; Grandgenett, P.M.; Caffrey, T.; O'Connell, K.A.; Swanson, B.; Marcos-Silva, L.; et al. Isoforms of MUC16 activate oncogenic signaling through EGF receptors to enhance the progression of pancreatic cancer. Mol. Ther. 2021, 29, 1557-1571. [CrossRef]

61. Yu, A.L.; Gilman, A.L.; Ozkaynak, M.F.; Naranjo, A.; Diccianni, M.B.; Gan, J.; Hank, J.A.; Batova, A.; London, W.B.; Tenney, S.C.; et al. Long-Term Follow-up of a Phase III Study of ch14.18 (Dinutuximab) + Cytokine Immunotherapy in Children with High-Risk Neuroblastoma: COG Study ANBL0032. Clin. Cancer Res. 2021, 27, 2179-2189. [CrossRef] [PubMed]

62. Aldeghaither, D.S.; Zahavi, D.J.; Murray, J.C.; Fertig, E.J.; Graham, G.T.; Zhang, Y.W.; O'Connell, A.; Ma, J.; Jablonski, S.A.; Weiner, L.M. A Mechanism of Resistance to Antibody-Targeted Immune Attack. Cancer Immunol. Res. 2019, 7, 230-243. [CrossRef] [PubMed]

63. Pietrantonio, F.; Fucà, G.; Morano, F.; Gloghini, A.; Corso, S.; Aprile, G.; Perrone, F.; De Vita, F.; Tamborini, E.; Tomasello, G.; et al. Biomarkers of Primary Resistance to Trastuzumab in HER2-Positive Metastatic Gastric Cancer Patients: The AMNESIA Case-Control Study. Clin. Cancer Res. 2018, 24, 1082-1089. [CrossRef] [PubMed]

64. Mishima, Y.; Terui, Y.; Takeuchi, K.; Matsumoto-Mishima, Y.; Matsusaka, S.; Utsubo-Kuniyoshi, R.; Hatake, K. The identification of irreversible rituximab-resistant lymphoma caused by CD20 gene mutations. Blood Cancer J. 2011, 1, e15. [CrossRef]

65. Sickmier, E.A.; Kurzeja, R.J.; Michelsen, K.; Vazir, M.; Yang, E.; Tasker, A.S. The Panitumumab EGFR Complex Reveals a Binding Mechanism That Overcomes Cetuximab Induced Resistance. PLoS ONE 2016, 11, e0163366. [CrossRef] [PubMed]

66. Thurber, G.M.; Schmidt, M.M.; Wittrup, K.D. Antibody tumor penetration: Transport opposed by systemic and antigen-mediated clearance. Adv. Drug Deliv. Rev. 2008, 60, 1421-1434. [CrossRef] [PubMed] 
67. Koh, X.Y.; Koh, X.H.; Hwang, L.A.; Ferrer, F.J.; Rahmat, S.A.B.; Lama, D.; Lane, D.P. Therapeutic anti-cancer activity of antibodies targeting sulfhydryl bond constrained epitopes on unglycosylated RON receptor tyrosine kinase. Oncogene 2019, 38, 7342-7356. [CrossRef] [PubMed]

68. Wang, Y.-N.; Lee, H.-H.; Hsu, J.L.; Yu, D.; Hung, M.-C. The impact of PD-L1 N-linked glycosylation on cancer therapy and clinical diagnosis. J. Biomed. Sci. 2020, 27, 77. [CrossRef]

69. Lee, H.H.; Wang, Y.N.; Xia, W.; Chen, C.H.; Rau, K.M.; Ye, L.; Wei, Y.; Chou, C.K.; Wang, S.C.; Yan, M.; et al. Removal of N-Linked Glycosylation Enhances PD-L1 Detection and Predicts Anti-PD-1/PD-L1 Therapeutic Efficacy. Cancer Cell 2019, 36, 168-178. [CrossRef] [PubMed]

70. Kaur, H. Characterization of glycosylation in monoclonal antibodies and its importance in therapeutic antibody development. Crit. Rev. Biotechnol. 2021, 41, 300-315. [CrossRef] [PubMed]

71. Shields, R.L.; Lai, J.; Keck, R.; O'Connell, L.Y.; Hong, K.; Meng, Y.G.; Weikert, S.H.; Presta, L.G. Lack of fucose on human IgG1 N-linked oligosaccharide improves binding to human Fcgamma RIII and antibody-dependent cellular toxicity. J. Biol. Chem. 2002, 277, 26733-26740. [CrossRef]

72. Ferrara, C.; Stuart, F.; Sondermann, P.; Brünker, P.; Umaña, P. The carbohydrate at FcgammaRIIIa Asn-162. An element required for high affinity binding to non-fucosylated IgG glycoforms. J. Biol. Chem. 2006, 281, 5032-5036. [CrossRef] [PubMed]

73. Scallon, B.J.; Tam, S.H.; McCarthy, S.G.; Cai, A.N.; Raju, T.S. Higher levels of sialylated Fc glycans in immunoglobulin G molecules can adversely impact functionality. Mol. Immunol. 2007, 44, 1524-1534. [CrossRef]

74. Hodoniczky, J.; Zheng, Y.Z.; James, D.C. Control of recombinant monoclonal antibody effector functions by Fc N-glycan remodeling in vitro. Biotechnol. Prog. 2005, 21, 1644-1652. [CrossRef]

75. Goetze, A.M.; Liu, Y.D.; Zhang, Z.; Shah, B.; Lee, E.; Bondarenko, P.V.; Flynn, G.C. High-mannose glycans on the Fc region of therapeutic IgG antibodies increase serum clearance in humans. Glycobiology 2011, 21, 949-959. [CrossRef]

76. Elshiaty, M.; Schindler, H.; Christopoulos, P. Principles and Current Clinical Landscape of Multispecific Antibodies against Cancer. Int. J. Mol. Sci. 2021, 22, 5632. [CrossRef]

77. Lutterbuese, R.; Raum, T.; Kischel, R.; Hoffmann, P.; Mangold, S.; Rattel, B.; Friedrich, M.; Thomas, O.; Lorenczewski, G.; Rau, D.; et al. T cell-engaging BiTE antibodies specific for EGFR potently eliminate KRAS- and BRAF-mutated colorectal cancer cells. Proc. Natl. Acad. Sci. USA 2010, 107, 12605-12610. [CrossRef]

78. Huhalov, A.; Adams, S.; Paragas, V.; Oyama, S.; Overland, R.; Luus, L.; Gibbons, F.; Zhang, B.; Nguyen, S.; Nielsen, U.B.; et al Abstract 3485: MM-111, an ErbB2/ErbB3 bispecific antibody with potent activity in ErbB2-overexpressing cells, positively combines with trastuzumab to inhibit growth of breast cancer cells driven by the ErbB2/ErbB3 oncogenic unit. Cancer Res. 2010, 70, 3485. [CrossRef]

79. Drago, J.Z.; Modi, S.; Chandarlapaty, S. Unlocking the potential of antibody-drug conjugates for cancer therapy. Nat. Rev. Clin. Oncol. 2021, 18, 327-344. [CrossRef] [PubMed]

80. Hafeez, U.; Parakh, S.; Gan, H.K.; Scott, A.M. Antibody-Drug Conjugates for Cancer Therapy. Molecules 2020, 25, 4764. [CrossRef]

81. Boni, V.; Sharma, M.R.; Patnaik, A. The Resurgence of Antibody Drug Conjugates in Cancer Therapeutics: Novel Targets and Payloads. Am. Soc. Clin. Oncol. Educ Book 2020, 40, 1-17. [CrossRef] [PubMed]

82. Hunter, F.W.; Barker, H.R.; Lipert, B.; Rothé, F.; Gebhart, G.; Piccart-Gebhart, M.J.; Sotiriou, C.; Jamieson, S.M.F. Mechanisms of resistance to trastuzumab emtansine (T-DM1) in HER2-positive breast cancer. Br. J. Cancer 2020, 122, 603-612. [CrossRef] [PubMed]

83. Lonial, S.; Lee, H.C.; Badros, A.; Trudel, S.; Nooka, A.K.; Chari, A.; Abdallah, A.O.; Callander, N.; Lendvai, N.; Sborov, D.; et al Belantamab mafodotin for relapsed or refractory multiple myeloma (DREAMM-2): A two-arm, randomised, open-label, phase 2 study. Lancet Oncol. 2020, 21, 207-221. [CrossRef]

84. Modi, S.; Saura, C.; Yamashita, T.; Park, Y.H.; Kim, S.B.; Tamura, K.; Andre, F.; Iwata, H.; Ito, Y.; Tsurutani, J.; et al. Trastuzumab Deruxtecan in Previously Treated HER2-Positive Breast Cancer. N. Engl. J. Med. 2020, 382, 610-621. [CrossRef]

85. Bardia, A.; Mayer, I.A.; Vahdat, L.T.; Tolaney, S.M.; Isakoff, S.J.; Diamond, J.R.; O'Shaughnessy, J.; Moroose, R.L.; Santin, A.D.; Abramson, V.G.; et al. Sacituzumab Govitecan-hziy in Refractory Metastatic Triple-Negative Breast Cancer. N. Engl. J. Med. 2019, 380, 741-751. [CrossRef]

86. Kantarjian, H.M.; DeAngelo, D.J.; Stelljes, M.; Martinelli, G.; Liedtke, M.; Stock, W.; Gökbuget, N.; O’Brien, S.; Wang, K.; Wang, T.; et al. Inotuzumab Ozogamicin versus Standard Therapy for Acute Lymphoblastic Leukemia. N. Engl. J. Med. 2016, 375, 740-753. [CrossRef]

87. Goldenson, B.H.; Goodman, A.M.; Ball, E.D. Gemtuzumab ozogamicin for the treatment of acute myeloid leukemia in adults. Expert Opin. Biol. Ther. 2021, 21, 849-862. [CrossRef] [PubMed]

88. Feldman, T.; Zou, D.; Rebeira, M.; Lee, J.; Fanale, M.; Manley, T.; Rao, S.; Feliciano, J.; Harris, M.; Kansal, A. Cost-effectiveness of brentuximab vedotin with chemotherapy in treatment of CD30-expressing PTCL. Am. J. Manag. Care 2020, 26, e41-e49. [CrossRef]

89. Sehn, L.H.; Herrera, A.F.; Flowers, C.R.; Kamdar, M.K.; McMillan, A.; Hertzberg, M.; Assouline, S.; Kim, T.M.; Kim, W.S.; Ozcan, M.; et al. Polatuzumab Vedotin in Relapsed or Refractory Diffuse Large B-Cell Lymphoma. J. Clin. Oncol. 2020, 38, 155-165. [CrossRef] [PubMed]

90. Xiao, H.; Woods, E.C.; Vukojicic, P.; Bertozzi, C.R. Precision glycocalyx editing as a strategy for cancer immunotherapy. Proc. Natl. Acad. Sci. USA 2016, 113, 10304-10309. [CrossRef] [PubMed] 
91. Jin, C.; Wang, K.; Oppong-Gyebi, A.; Hu, J. Application of Nanotechnology in Cancer Diagnosis and Therapy-A Mini-Review. Int. J. Med. Sci. 2020, 17, 2964-2973. [CrossRef]

92. Ali, E.S.; Sharker, S.M.; Islam, M.T.; Khan, I.N.; Shaw, S.; Rahman, M.A.; Uddin, S.J.; Shill, M.C.; Rehman, S.; Das, N.; et al Targeting cancer cells with nanotherapeutics and nanodiagnostics: Current status and future perspectives. Semin. Cancer Biol. 2021, 69, 52-68. [CrossRef]

93. Marques, A.C.; Costa, P.J.; Velho, S.; Amaral, M.H. Functionalizing nanoparticles with cancer-targeting antibodies: A comparison of strategies. J. Control. Release 2020, 320, 180-200. [CrossRef]

94. Parakh, S.; King, D.; Gan, H.K.; Scott, A.M. Current Development of Monoclonal Antibodies in Cancer Therapy. Recent Results Cancer Res. 2020, 214, 1-70. [CrossRef]

95. Khan, H.; Mirzaei, H.R.; Amiri, A.; Kupeli Akkol, E.; Ashhad Halimi, S.M.; Mirzaei, H. Glyco-nanoparticles: New drug delivery systems in cancer therapy. Semin. Cancer Biol. 2021, 69, 24-42. [CrossRef]

96. Arslan, F.B.; Ozturk Atar, K.; Calis, S. Antibody-mediated drug delivery. Int. J. Pharm. 2021, 596, 120268. [CrossRef]

97. Richards, D.A.; Maruani, A.; Chudasama, V. Antibody fragments as nanoparticle targeting ligands: A step in the right direction. Chem. Sci. 2017, 8, 63-77. [CrossRef] [PubMed]

98. Andrade, F.; Rafael, D.; Vilar-Hernández, M.; Montero, S.; Martínez-Trucharte, F.; Seras-Franzoso, J.; Díaz-Riascos, Z.V.; Boullosa, A.; García-Aranda, N.; Cámara-Sánchez, P.; et al. Polymeric micelles targeted against CD44v6 receptor increase niclosamide efficacy against colorectal cancer stem cells and reduce circulating tumor cells in vivo. J. Control. Release 2021, 331, 198-212. [CrossRef]

99. Baião, A.; Sousa, F.; Oliveira, A.V.; Oliveira, C.; Sarmento, B. Effective intracellular delivery of bevacizumab via PEGylated polymeric nanoparticles targeting the CD44v6 receptor in colon cancer cells. Biomater Sci. 2020, 8, 3720-3729. [CrossRef] [PubMed]

100. Torres-Pérez, S.A.; Torres-Pérez, C.E.; Pedraza-Escalona, M.; Pérez-Tapia, S.M.; Ramón-Gallegos, E. Glycosylated Nanoparticles for Cancer-Targeted Drug Delivery. Front. Oncol. 2020, 10. [CrossRef]

101. Mateu Ferrando, R.; Lay, L.; Polito, L. Gold nanoparticle-based platforms for vaccine development. Drug Discov. Today Technol. 2020, 38, 57-67. [CrossRef]

102. Anderluh, M.; Berti, F.; Bzducha-Wróbel, A.; Chiodo, F.; Colombo, C.; Compostella, F.; Durlik, K.; Ferhati, X.; Holmdahl, R.; Jovanovic, D.; et al. Recent advances on smart glycoconjugate vaccines in infections and cancer. FEBS J. 2021. [CrossRef]

103. Liu, Y.; Wang, Z.; Yu, F.; Li, M.; Zhu, H.; Wang, K.; Meng, M.; Zhao, W. The Adjuvant of $\alpha$-Galactosylceramide Presented by Gold Nanoparticles Enhances Antitumor Immune Responses of MUC1 Antigen-Based Tumor Vaccines. Int. J. Nanomed. 2021, 16, 403-420. [CrossRef] [PubMed]

104. Cai, H.; Degliangeli, F.; Palitzsch, B.; Gerlitzki, B.; Kunz, H.; Schmitt, E.; Fiammengo, R.; Westerlind, U. Glycopeptidefunctionalized gold nanoparticles for antibody induction against the tumor associated mucin-1 glycoprotein. Bioorg. Med. Chem. 2016, 24, 1132-1135. [CrossRef]

105. Mocan, T.; Matea, C.; Tabaran, F.; Iancu, C.; Orasan, R.; Mocan, L. In Vitro Administration of Gold Nanoparticles Functionalized with MUC-1 Protein Fragment Generates Anticancer Vaccine Response via Macrophage Activation and Polarization Mechanism. J. Cancer 2015, 6, 583-592. [CrossRef]

106. Parry, A.L.; Clemson, N.A.; Ellis, J.; Bernhard, S.S.; Davis, B.G.; Cameron, N.R. 'Multicopy multivalent' glycopolymer-stabilized gold nanoparticles as potential synthetic cancer vaccines. J. Am. Chem. Soc. 2013, 135, 9362-9365. [CrossRef]

107. Trabbic, K.R.; Kleski, K.A.; Barchi, J.J., Jr. A Stable Gold Nanoparticle-Based Vaccine for the Targeted Delivery of Tumor-Associated Glycopeptide Antigens. ACS Bio Med. Chem. Au 2021, 1, 31-43. [CrossRef]

108. Hamdy, S.; Haddadi, A.; Shayeganpour, A.; Samuel, J.; Lavasanifar, A. Activation of antigen-specific T cell-responses by mannan-decorated PLGA nanoparticles. Pharm. Res. 2011, 28, 2288-2301. [CrossRef] [PubMed]

109. Ye, J.; Yang, Y.; Dong, W.; Gao, Y.; Meng, Y.; Wang, H.; Li, L.; Jin, J.; Ji, M.; Xia, X.; et al. Drug-free mannosylated liposomes inhibit tumor growth by promoting the polarization of tumor-associated macrophages. Int. J. Nanomed. 2019, 14, 3203-3220. [CrossRef] [PubMed]

110. Yu, C.; Hu, Y.; Duan, J.; Yuan, W.; Wang, C.; Xu, H.; Yang, X.D. Novel aptamer-nanoparticle bioconjugates enhances delivery of anticancer drug to MUC1-positive cancer cells in vitro. PLoS ONE 2011, 6, e24077. [CrossRef] [PubMed]

111. Sayari, E.; Dinarvand, M.; Amini, M.; Azhdarzadeh, M.; Mollarazi, E.; Ghasemi, Z.; Atyabi, F. MUC1 aptamer conjugated to chitosan nanoparticles, an efficient targeted carrier designed for anticancer SN38 delivery. Int. J. Pharm. 2014, 473, 304-315. [CrossRef]

112. Hanafi-Bojd, M.Y.; Moosavian Kalat, S.A.; Taghdisi, S.M.; Ansari, L.; Abnous, K.; Malaekeh-Nikouei, B. MUC1 aptamer-conjugated mesoporous silica nanoparticles effectively target breast cancer cells. Drug Dev. Ind. Pharm. 2018, 44, 13-18. [CrossRef]

113. Perepelyuk, M.; Sacko, K.; Thangavel, K.; Shoyele, S.A. Evaluation of MUC1-Aptamer Functionalized Hybrid Nanoparticles for Targeted Delivery of miRNA-29b to Nonsmall Cell Lung Cancer. Mol. Pharm. 2018, 15, 985-993. [CrossRef]

114. Bashir, A.; Yang, Q.; Wang, J.; Hoyer, S.; Chou, W.; McLean, C.; Davis, G.; Gong, Q.; Armstrong, Z.; Jang, J.; et al. Machine learning guided aptamer refinement and discovery. Nat. Commun. 2021, 12, 2366. [CrossRef]

115. Jafari, R.; Majidi Zolbanin, N.; Majidi, J.; Atyabi, F.; Yousefi, M.; Jadidi-Niaragh, F.; Aghebati-Maleki, L.; Shanehbandi, D.; Soltani Zangbar, M.S.; Rafatpanah, H. Anti-Mucin1 Aptamer-Conjugated Chitosan Nanoparticles for Targeted Co-Delivery of Docetaxel and IGF-1R siRNA to SKBR3 Metastatic Breast Cancer Cells. Iran. Biomed. J. 2019, 23, 21-33. [CrossRef] 
116. Skandalis, S.S.; Gialeli, C.; Theocharis, A.D.; Karamanos, N.K. Advances and advantages of nanomedicine in the pharmacological targeting of hyaluronan-CD44 interactions and signaling in cancer. Adv. Cancer Res. 2014, 123, 277-317. [CrossRef]

117. Ahir, M.; Upadhyay, P.; Ghosh, A.; Sarker, S.; Bhattacharya, S.; Gupta, P.; Ghosh, S.; Chattopadhyay, S.; Adhikary, A. Delivery of dual miRNA through CD44-targeted mesoporous silica nanoparticles for enhanced and effective triple-negative breast cancer therapy. Biomater. Sci. 2020, 8, 2939-2954. [CrossRef] [PubMed]

118. Liang, Y.; Wang, Y.; Wang, L.; Liang, Z.; Li, D.; Xu, X.; Chen, Y.; Yang, X.; Zhang, H.; Niu, H. Self-crosslinkable chitosan-hyaluronic acid dialdehyde nanoparticles for CD44-targeted siRNA delivery to treat bladder cancer. Bioact. Mater. 2021, 6, 433-446. [CrossRef] [PubMed]

119. Kennedy, P.J.; Sousa, F.; Ferreira, D.; Pereira, C.; Nestor, M.; Oliveira, C.; Granja, P.L.; Sarmento, B. Fab-conjugated PLGA nanoparticles effectively target cancer cells expressing human CD44v6. Acta Biomater. 2018, 81, 208-218. [CrossRef] [PubMed]

120. Correa, T.D.S.; Bocca, A.L.; Figueiredo, F.; Lima, E.C.O.; Almeida Santos, M.F.M.; Lacava, Z.G.M.; Campos-da-Paz, M. Anti-CEA tagged iron nanoparticles for targeting triple-negative breast cancer. Biomed. Mater. 2021. [CrossRef]

121. Pereira, I.; Sousa, F.; Kennedy, P.; Sarmento, B. Carcinoembryonic antigen-targeted nanoparticles potentiate the delivery of anticancer drugs to colorectal cancer cells. Int. J. Pharm. 2018, 549, 397-403. [CrossRef]

122. Fernandes, E.; Ferreira, D.; Peixoto, A.; Freitas, R.; Relvas-Santos, M.; Palmeira, C.; Martins, G.; Barros, A.; Santos, L.L.; Sarmento, B.; et al. Glycoengineered nanoparticles enhance the delivery of 5-fluoroucil and paclitaxel to gastric cancer cells of high metastatic potential. Int. J. Pharm. 2019, 570, 118646. [CrossRef]

123. Palma-Chavez, J.A.; Fuentes, K.; Applegate, B.E.; Jo, J.A.; Charoenphol, P. Development and Characterization of PLGABased Multistage Delivery System for Enhanced Payload Delivery to Targeted Vascular Endothelium. Macromol. Biosci. 2021, 21, e2000377. [CrossRef]

124. Alhallak, K.; Sun, J.; Muz, B.; Jeske, A.; Yavner, J.; Bash, H.; Park, C.; Lubben, B.; Adebayo, O.; Achilefu, S.; et al. Nanoparticle T cell engagers for the treatment of acute myeloid leukemia. Oncotarget 2021, 12, 1878-1885. [CrossRef]

125. Niu, F.; Yan, J.; Ma, B.; Li, S.; Shao, Y.; He, P.; Zhang, W.; He, W.; Ma, P.X.; Lu, W. Lanthanide-doped nanoparticles conjugated with an anti-CD33 antibody and a p53-activating peptide for acute myeloid leukemia therapy. Biomaterials 2018, 167, 132-142. [CrossRef]

126. Hansel, T.T.; Kropshofer, H.; Singer, T.; Mitchell, J.A.; George, A.J. The safety and side effects of monoclonal antibodies. Nat. Rev. Drug Discov. 2010, 9, 325-338. [CrossRef]

127. Li, H.; Xu, S.; Quan, J.; Yung, B.C.; Pang, J.; Zhou, C.; Cho, Y.A.; Zhang, M.; Liu, S.; Muthusamy, N.; et al. CD33-Targeted Lipid Nanoparticles (aCD33LNs) for Therapeutic Delivery of GTI-2040 to Acute Myelogenous Leukemia. Mol. Pharm. 2015, 12, 2010-2018. [CrossRef]

128. Chen, W.C.; Kawasaki, N.; Nycholat, C.M.; Han, S.; Pilotte, J.; Crocker, P.R.; Paulson, J.C. Antigen delivery to macrophages using liposomal nanoparticles targeting sialoadhesin/CD169. PLoS ONE 2012, 7, e39039. [CrossRef]

129. Martínez-Carmona, M.; Lozano, D.; Colilla, M.; Vallet-Regí, M. Lectin-conjugated pH-responsive mesoporous silica nanoparticles for targeted bone cancer treatment. Acta Biomater. 2018, 65, 393-404. [CrossRef] [PubMed]

130. Wang, R.; Huang, J.; Chen, J.; Yang, M.; Wang, H.; Qiao, H.; Chen, Z.; Hu, L.; Di, L.; Li, J. Enhanced anti-colon cancer efficacy of 5-fluorouracil by epigallocatechin-3- gallate co-loaded in wheat germ agglutinin-conjugated nanoparticles. Nanomedicine 2019, 21, 102068. [CrossRef]

131. Bhat, R.; García, I.; Aznar, E.; Arnaiz, B.; Martínez-Bisbal, M.C.; Liz-Marzán, L.M.; Penadés, S.; Martínez-Máñez, R. Lectin-gated and glycan functionalized mesoporous silica nanocontainers for targeting cancer cells overexpressing Lewis $\mathrm{X}$ antigen. Nanoscale 2017, 10, 239-249. [CrossRef] [PubMed]

132. Della Giovampaola, C.; Capone, A.; Ermini, L.; Lupetti, P.; Vannuccini, E.; Finetti, F.; Donnini, S.; Ziche, M.; Magnani, A.; Leone, G.; et al. Formulation of liposomes functionalized with Lotus lectin and effective in targeting highly proliferative cells. Biochim. Biophys. Acta Gen. Subj. 2017, 1861, 860-870. [CrossRef]

133. Dutta Chowdhury, A.; Ganganboina, A.B.; Tsai, Y.-c.; Chiu, H.-c.; Doong, R.-a. Multifunctional GQDs-Concanavalin A@Fe3O4 nanocomposites for cancer cells detection and targeted drug delivery. Anal. Chim. Acta 2018, 1027, 109-120. [CrossRef] [PubMed] 